\title{
REVIEW
}

\section{Biomarkers of Bronchial Asthma}

\author{
Peter KUNC ${ }^{1}$, Jaroslav FABRY ${ }^{1}$, Miroslava LUCANSKA ${ }^{2}$, Renata PECOVA ${ }^{3}$ \\ ${ }^{1}$ Clinic of Pediatric Respiratory Diseases and Tuberculosis in National Institute of Pediatric \\ Tuberculosis and Respiratory Diseases in Dolny Smokovec, Jessenius Faculty of Medicine in \\ Martin, Comenius University in Bratislava, Slovak Republic, ${ }^{2}$ Clinic of Otorhinolaryngology and \\ Head and Neck Surgery, Jessenius Faculty of Medicine in Martin, Comenius University in \\ Bratislava, University Hospital in Martin, Martin, Slovak Republic, ${ }^{3}$ Department of Pathological \\ Physiology, Jessenius Faculty of Medicine in Martin, Comenius University in Bratislava, Martin, \\ Slovak Republic
}

Received October 3, 2019

Accepted November 28, 2019

\begin{abstract}
Summary
Asthma is a complex disease with a variable course. Efforts to identify biomarkers to predict asthma severity, the course of disease and response to treatment have not been very successful so far. Biomarker research has expanded greatly with the advancement of molecular research techniques. An ideal biomarker should be suitable to identify the disease as well the specific endotype/phenotype, useful in the monitoring of the disease and to determine the prognosis, easily to obtain with minimum discomfort or risk to the patient. An ideal biomarker should be suitable to identify the disease as well the specific endotype/phenotype, useful in the monitoring of the disease and to determine the prognosis, easily to obtain with minimum discomfort or risk to the patient - exhaled breath analysis, blood cells and serum biomarkers, sputum cells and mediators and urine metabolites could be potential biomarkers of asthma bronchiale. Unfortunately, at the moment, an ideal biomarker doesn't exist and the overlap between the biomarkers is a reality. Using panels of biomarkers could improve probably the identification of asthma endotypes in the era of precision medicine.
\end{abstract}

\section{Key words}

Biomarkers • Bronchial asthma

\section{Corresponding author}

R. Péčová, Department of Pathological Physiology, Jessenius Faculty of Medicine in Martin, Comenius University Bratislava, Malá Hora 4C, 03601 Martin, Slovak Republic. E-mail: renata.pecova@uniba.sk

\section{Introduction}

Asthma is a complex disease with multiple phenotypes (Papi et al. 2018). With the increasing prevalence of bronchial asthma, the continuous lack of novel therapies and inefficient disease prevention, the demand for predictive biomarkers for allergic rhinitis and asthma is steadily increasing. Following the current clinical guidelines, it is essential to identify allergen sensitization patterns as well as lung function parameters (Zissler et al. 2015). Besides genetic predisposition, immunological changes in the airways may provide important information for allergic disease endotypes. Biomarker research has expanded greatly with the advancement of molecular research techniques. An ideal biomarker should be suitable to identify the disease as well the specific endotype/phenotype, useful in the monitoring of the disease and to determine the prognosis, easily to obtain with minimum discomfort or risk to the patient (Fitzpatrick 2015). The aim of this study is to provide a basic overview of biomarkers in asthma.

\section{Exhaled breath analysis}

Exhaled breath condensate (EBC) is a noninvasive method of sampling the airway environment. It analyses both volatile and non-volatile compounds by saturating exhaled breath with water vapour and collecting 
the condensed material. Examples of compounds collected in EBC include nitric oxide products, hydrogen peroxide, leukotrienes, and cytokines. Several components correlate with the asthma diagnosis, others with asthma severity (Medrek et al. 2017).

Fractional nitric oxide in the exhaled breath (FeNO) provides information about the inflammatory state of the airways (Dweik et al. 2011, Antosova et al. 2017a, Antosova et al. 2017b). Nitric oxide plays key roles in lung biology as bronchodilator and inflammatory mediator and is produced in the lung from nitric oxide synthases during the conversion of the amino acid L-arginine to L-citrulline. The biomarker FeNO is originated from nitric oxide production by the airway epithelium as a result of inducible nitric oxide synthase upregulation during the process of allergic inflammation (Fitzpatrick 2015, Topercerova et al. 2019). FeNO as a single, stand-alone biomarker might not be particularly useful and should perhaps be used as part of a more comprehensive panel (Fitzpatrick 2015). The current guidelines for the treatment of severe asthma do not recommend the use of FeNO in the routine for the management of adults and children with asthma (Chung et al. 2011). The measurement of exhaled volatile organic compounds by gas chromatography coupled with mass spectrometry could predict the risk for exacerbation in asthmatic children (Robroeks et al. 2013). These promising methods need to be standardised before a plus large implementation.

\section{Blood cells and serum biomarkers}

Blood eosinophil count is not useful for the diagnosis of asthma (GINA), but it can serve as a prognostic biomarker and predict several therapeutic responses (Eguiluz-Gracia et al. 2018) in asthmatic patients with type 2 inflammation.

Currently, blood neutrophils count is not a biomarker for asthma diagnosis (GINA).

Eosinophil cationic protein $(E C P)$ is found in the primary matrix of the eosinophil and is released during the eosinophil degranulation. Previous data found that serum ECP is increased in adults and children with atopic asthma, associated with airway resistance and bronchospasm (Koh et al. 2007). It has been suggested that ECP assessment could be useful for the initiation and dose titration of inhaled corticosteroids in younger children in whom other biomarkers might be less feasible to asses (Fitzpatrick 2015), but other complementary studies are needed to validate this strategy (Tiotiu 2018).
Lipoxins have anti-inflammatory action and play an important role in chemotaxis and related signal transduction (Fitzpatrick 2015).

Periostin, an extracellular matrix protein secreted by airway epithelial cells in response to IL-13 that regulates epithelial-mesenchymal interactions (Fitzpatrick 2015), has been associated with T2-high eosinophilic asthma (Grayson et al. 2018). Periostin expression is increased in the asthmatic airway (Lopez-Guisa et al. 2012). The stability of serum periostin over disease progression in adults with asthma (without seasonal effect) (Semprini et al. 2018) supports its use as a biomarker for type 2-high asthma.

$\operatorname{IgE}$ is an immunoglobulin which mediates type 1 hypersensitivity reactions and plays a key role in the pathogenesis of allergic asthma. It binds to IgE receptors on mast cells and basophils, producing cytokines that mediate T2 responses (Medrek et al. 2017). Serum IgE closely correlates with the risk of asthma (Burrows et al. 1989).

Chitinases are hydrolases characterised by their affinity to cleave chitin that are thought to play a role in remodelling and regulation of the extracellular matrix (Fitzpatrick 2015). The chitinase-like protein YKL-40 (human cartilage glycoprotein 39) same to be an interesting biomarker for distinguishing asthma from chronic obstructive pulmonary disease (COPD) and healthy controls (James et al. 2016). More studies are needed to prove how useful YKL-40 is in the assessment of future asthma outcomes and risk (Tiotiu 2018).

Recent data showed that airway mucosal expression of CCL26 (the most differentially expressed gene) is the best discriminator for type 2 inflammation (Silkoff et al. 2017), serum urokinase plasminogen activated receptor is elevated in adult patients with severe, non-atopic asthma (Portelli et al. 2017), and the expression of ten selected microRNA (HS_108.1, 112, 182.1, 240, 261.1, 3, 55.1, 91.1, has-miR-604, and has-miR-638) is higher in children with severe asthma (Midyat et al. 2016). Serum high-sensitive C-reactive protein (hs-CRP) is increased in asthmatic patients than in healthy control, in poorly controlled vs well controlled, and may represent a useful biomarker of airway inflammation in nonsmoking asthmatic patients without complications, such as heart disease, hypertension, hyperlipidaemia, chronic obstructive pulmonary disease, or infection (Shimoda et al. 2015). Evaluation of inflammatory markers interleukin6 (IL-6) and matrix metalloproteinase-9 (MMP-9) in serum showed higher levels in asthmatic patients vs 
controls and were associated with more severe asthma (Naik et al. 2018). A high serum level of $I L-8$ could discriminate COPD from asthma patients (Liu et al. 2014).

Although all advantages of serum biomarkers, it is important to remember that peripheral blood studies often do not reflect airway biology, and therefore peripheral blood biomarkers might not represent physiologic mechanisms in the airways (Grayson et al. 2018).

\section{Sputum cells and mediators}

Induced sputum is a non-invasive method which allows quantifying the inflammatory cell pattern in airways of asthmatic patients. To obtain samples for sputum analysis, patients nebulize $3 \%$ saline for $20 \mathrm{~min}$ and the sputum expectorated over this period is centrifuged, stained, and analysed by quantifying the number of different cell types (Medrek et al. 2017).

Sputum quantitative cell count is the reference standard to reflect the airway inflammation in asthma. The practical advantage of sputum differential cell counts is that this method is feasible even on frozen samples (Eguiluz-Gracia et al. 2018). Four inflammatory phenotypes have been identified in the Severe Asthma Research Program (SARP) cohort - eosinophilic ( $\geq 2 \%$ eosinophils in induced sputum), neutrophilic ( $\geq 40 \%$ neutrophils), mixed granulocytic and paucigranulocytic (Moore et al. 2013). The presence of sputum neutrophilia is one candidate predictive biomarker for non-T2 asthma (Medrek et al. 2017).

Changes in sputum eosinophil count over time reflect fluctuations in clinical asthma control (Demarche $e t$ al. 2017). The high level of the innate lymphoid cell (Group 2 ILC) in the sputum is correlated with severe asthma suggesting these cells could be a potential novel biomarker (Cowan et al. 2015).

Unfortunately, despite its use as a biomarker in many clinical trials, the use of sputum cells count in daily practice has limitations. This method requires specialized training, equipment, and laboratory for processing, patient coaching and cooperation, emergency protocols and equipment, is difficult to collect (impossible in young children), not easily repeatable, and had several contraindications (Fitzpatrick 2015).

Several sputum mediators could be the potential biomarkers. For the diagnostic of inflammatory pattern, sputum eosinophil peroxidase is correlated with sputum eosinophilia (Nair et al. 2013). Specific microRNAs could discriminate neutrophilic from eosinophilic asthma (Maes et al. 2016), and neutrophil myeloperoxidase has the potential to differentiate asthma COPD overlap syndrome from asthma (Iwamoto et al. 2014). As a prognostic biomarker, sputum expression of human tumour necrosis factor-like weak inducer of apoptosis correlates with higher severity, poor asthma control and decreased lung function in children with non-eosinophilic asthma (Kim et al. 2018).

\section{Urine metabolites}

Bromotyrosine is formed from post-translational modification of tyrosine protein residues by hypobromous acid produced by activated eosinophils during the process of a respiratory burst. It has many advantages as a potential biomarker given its stability and non-invasive detection in the urine. The utility of bromotyrosine in the clinical setting would probably be best when assessed as a part of a larger panel of inflammatory biomarkers (Fitzpatrick 2015).

Leukotriene $E_{4}$ is a stable and product of cysteinyl leukotriene metabolism possible to be measured noninvasively in urine samples. Urinary leukotriene $E_{4}$ (uLTE4) concentrations are increased in children with allergic asthma and adults with aspirin-exacerbated respiratory disease (Fitzpatrick 2015). Several studies suggest that uLTE4 might be an important biomarker in the selection of asthma therapy (Tiotiu 2018).

\section{Discussion}

In asthma, and particularly in severe asthma, many biomarkers have been investigated but only a few of them can be easily used in clinical practice so far (Canonica et al. 2018). An ideal biomarker should be suitable to identify the disease as well the specific endotype/phenotype, useful in the monitoring of the disease and to determine the prognosis, easily to obtain with minimum discomfort or risk to the patient (Eguiluz-Gracia et al. 2018). Unfortunately, an ideal biomarker doesn't exist and the overlap between the biomarkers is a reality at the moment. Using panels of biomarkers could probably improve the identification of asthma endotypes in the era of precision medicine (Tiotiu 2018).

In conclusion, further research and validation of emerging biomarkers are needed to define the molecular phenotype of asthma. Viewing the heterogeneity of asthma, the development of composite biomarkers from blood, urine and exhaled breath seems to be a more appropriate solution 
in practice to predict therapeutic response.

\section{Conflict of Interest}

There is no conflict of interest.

\section{Acknowledgements}

This work was supported by the project of Ministry of Health of the Slovak Republic - 2018/12-UKMT-8.

\section{References}

ANTOSOVA M, MOKRA D, PEPUCHA L, PLEVKOVA J, BUDAY T, STERUSKY M, BENCOVA A: Physiology of nitric oxide in the respiratory system. Physiol Res 66 (Suppl 2): S159-S172, 2017a. https://doi.org/10.33549/physiolres.933673

ANTOSOVA M, MOKRA D, TONHAJZEROVA I, MIKOLKA P, KOSUTOVA P, MESTANIK M, PEPUCHA L, PLEVKOVA J, BUDAY T, CALKOVSKY V, BENCOVA A: Nasal nitric oxide in healthy adults - reference values and affecting factors. Physiol Res 66 (Suppl 2): S247-S255, 2017b. https://doi.org/10.33549/physiolres.933680

CANONICA GW, FERRANDO M, BAIARDINI I, PUGGIONI F, RACCA F, PASSALACQUA G, HEFFLER E: Asthma: personalized and precision medicine. Curr Opin Allergy Clin Immunol 18: 51-58, 2018. https://doi.org/10.1097/ACI.0000000000000416

CHUNG KF, WENZEL SE, BROZEK JL, BUSH A, CASTRO M, STERK PJ, ADCOCK IM, BATEMAN ED, BEL EH, BLEECKER ER, BOULET LP, BRIGHTLING C, CHANEZ P, DAHLEN SE, DJUKANOVIC R, FREY U, GAGA M, GIBSON P, HAMID Q, JAJOUR NN, MAUAD T, SORKNESS RL, TEAGUE WG: International ERS/ATS guidelines on definition, evaluation and treatment of severe asthma. Eur Respir J 43: 343-373, 2014. https://doi.org/10.1183/09031936.00202013

COWAN DC, TAYLOR DR, PETERSON LE, COWAN JO, PALMAY R, WILLIAMSON A, HAMMEL J, ERZURUM SC, HAZEN SL, COMHAIR SA: Biomarker-based asthma phenotypes of corticosteroid response. J Allergy Clin Immunol 135: 877-883, 2015. https://doi.org/10.1016/j.jaci.2014.10.026

DEMARCHE SF, SCHLEICH FN, PAULUS VA, HENKET MA, VAN HEES TJ, LOUIS RE: Asthma control and sputum eosinophils: a longitudinal study in daily practice. J Allergy Clin Immunol Pract 5: 1335-1343, 2017. https://doi.org/10.1016/j.jaip.2017.01.026

DWEIK RA, BOGGS PB, ERZURUM SC, IRVIN CG, LEIGH MW, LUNDBERG JO, OLIN AC, PLUMMER AL, TAYLOR DR: American Thoracic Society Committee on Interpretation of Exhaled Nitric Oxide Levels (FENO) for Clinical Applications. An official ATS clinical practice guideline: interpretation of exhaled nitric oxide levels (FENO) for clinical applications. Am J Respir Crit Care Med 184: 602-615, 2011. https://doi.org/10.1164/rccm.9120-11ST

EGUILUZ-GRACIA I, TAY TR, HEW M, ESCRIBESE MM, BARBER D, O'HEHIR RE, TORRES MJ: Recent developments and highlights in biomarkers in allergic diseases and asthma. Allergy 73: 2290-2305, 2018. https://doi.org/10.1111/all.13628

FITZPATRICK AM: Biomarkers of asthma and allergic airway diseases. Ann Allergy Asthma Immunol 115: 335-340, 2015. https://doi.org/10.1016/j.anai.2015.09.003

GRAYSON MH, FELDMAN S, PRINCE BT, PATEL PJ, MATSUI EC, APTER AJ: Advances in asthma in 2017: Mechanisms, biologics, and genetics. J Allergy Clin Immunol 142: 1423-1436, 2018. https://doi.org/10.1016/j.jaci.2018.08.033

IWAMOTO H, GAO J, KOSKELA J, KINNULA V, KOBAYASHI H, LAITINEN T, MAZUR W: Differences in plasma and sputum biomarkers between COPD and COPD-asthma overlap. Eur Respir J 43: 421-429, 2014. https://doi.org/10.1183/09031936.00024313

KARRASCH S, LINDE K, RÜCKER G, SOMMER H, KARSCH-VÖLK M, KLEIJNEN J, JÖRRES RA, SCHNEIDER A: Accuracy of FENO for diagnosing asthma: a systematic review. Thorax 72: 109-116, 2017. https://doi.org/10.1136/thoraxjnl-2016-208704

KOH GC, SHEK LP, GOH DY, VAN BEVER H, KOH DS: Eosinophil cationic protein: is it useful in asthma? A systematic review. Respir Med 101: 696-705, 2007. https://doi.org/10.1016/j.rmed.2006.08.012 
LIU HC, LU MC, LIN YC, WU TC, HSU JY, JAN MS, CHEN CM: Differences in IL-8 in serum and exhaled breath condensate from patients with exacerbated COPD or asthma attacks. J Formos Med Assoc 113: 908-914, 2014. https://doi.org/10.1016/j.jfma.2012.09.018

LOPEZ-GUISA JM, POWERS C, FILE D, COCHRANE E, JIMENEZ N, DEBLEY JS: Airway epithelial cells from asthmatic children differentially express proremodeling factors. J Allergy Clin Immunol 129: 990-997, 2012. https://doi.org/10.1016/j.jaci.2011.11.035

MAES T, COBOS FA, SCHLEICH F, SORBELLO V, HENKET M, DE PRETER K, BRACKE KR, CONICKX G, MESNIL C, VANDESOMPELE J, LAHOUSSE L, BUREAU F, MESTDAGH P, JOOS GF, RICCIARDOLO FL, BRUSSELLE GG, LOUIS R: Asthma inflammatory phenotypes show differential microRNA expression in sputum. J Allergy Clin Immunol 137: 1433-1446, 2016. https://doi.org/10.1016/j.jaci.2016.02.018

MEDREK SK, PARULEKAR AD, HANANIA NA: Predictive biomarkers for asthma therapy. Curr Allergy Asthma Rep 17: 69, 2017. https://doi.org/10.1007/s11882-017-0739-5

MIDYAT L, GULEN F, KARACA E, OZKINAY F, TANAC R, DEMIR E, COGULU O, ASLAN A, OZKINAY C, ONAY H, ATASEVER M: MicroRNA expression profiling in children with different asthma phenotypes. Pediatr Pulmonol 51: 582-587, 2016. https://doi.org/10.1002/ppul.23331

MOORE WC, HASTIE AT, LI X, LI H, BUSSE WW, JARJOUR NN, WENZEL SE, PETERS SP, MEYERS DA, BLEECKER ER, National Heart, Lung, and Blood Institute's Severe Asthma Research Program: Sputum neutrophil counts are associated with more severe asthma phenotypes using cluster analysis. J Allergy Clin Immunol 133: 1557-1563, 2014. https://doi.org/10.1016/j.jaci.2013.10.011

NAIK SP, P A M, B S J, MADHUNAPANTULA SV, JAHROMI SR, YADAV MK: Evaluation of inflammatory markers interleukin-6 (IL-6) and matrix metalloproteinase-9(MMP-9) in asthma. J Asthma 54: 584-593, 2017. https://doi.org/10.1080/02770903.2016.1244828

NAIR P, OCHKUR SI, PROTHEROE C, RADFORD K, EFTHIMIADIS A, LEE NA, LEE JJ: Eosinophil peroxidase in sputum represents a unique biomarker of airway eosinophilia. Allergy 68: 1177-1184, 2013. https://doi.org/10.1111/all.12206

PAPI A, BRIGHTLING C, PEDERSEN SE, REDDEL HK: Asthma. Lancet 391: 783-800, 2018. https://doi.org/10.1016/S0140-6736(17)33311-1

PORTELLI MA, MOSELEY C, STEWART CE, POSTMA DS, HOWARTH P, WARNER JA, HOLLOWAY JW, KOPPELMAN GH, BRIGHTLING C, SAYERS I: Airway and peripheral urokinase plasminogen activator receptor is elevated in asthma, and identifies a severe, nonatopic subset of patients. Allergy 72: 473-482, 2017. https://doi.org/10.1111/all.13046

ROBROEKS CM, VAN BERKEL JJ, JÖBSIS Q, VAN SCHOOTEN FJ, DALLINGA JW, WOUTERS EF, DOMPELING E: Exhaled volatile organic compounds predict exacerbations of childhood asthma in a 1-year prospective study. Eur Respir J 42: 98-106, 2013. https://doi.org/10.1183/09031936.00010712

SEMPRINI R, CASWELL-SMITH R, FINGLETON J, HOLWEG C, MATTHEWS J, WEATHERALL M, BEASLEY R, BRAITHWAITE I: Periostin Study Team. Longitudinal variation periostin levels in adults with stable asthma. J Allergy Clin Immunol 139: 1687-1688, 2017. https://doi.org/10.1016/j.jaci.2016.11.041

SILKOFF PE, LAVIOLETTE M, SINGH D, FITZGERALD JM, KELSEN S, BACKER V, PORSBJERG CM, GIRODET PO, BERGER P, KLINE JN, CHUPP G, SUSULIC VS, BARIBAUD F, LOZA MJ, Airways Disease Endotyping for Personalized Therapeutics (ADEPT) study investigators: Identification of airway mucosal type 2 inflammation by using clinical biomarkers in asthmatic patients. J Allergy Clin Immunol 140: 710-719, 2017. https://doi.org/10.1016/j.jaci.2016.11.038

SCHNEIDER A, LINDE K, REITSMA JB, STEINHAUSER S, RÜCKER G: A novel statistical model for analyzing data of a systematic review generates optimal cutoff values for fractional exhaled nitric oxide for asthma diagnosis. J Clin Epidemiol 92: 69-78, 2017. https://doi.org/10.1016/j.jclinepi.2017.09.001

SHIMODA T, OBASE Y, KISHIKAWA R, IWANAGA T: Serum high-sensitivity C-reactive protein can be an airway inflammation predictor in bronchial asthma. Allergy Asthma Proc 36: e23-8, 2015. https://doi.org/10.2500/aap.2015.36.3816

TIOTIU A: Biomarkers in asthma: state of the art. Asthma Res Pract 4: 10, 2018. https://doi.org/10.1186/s40733-0180047-4 
TOPERCEROVA J, KOLOMAZNIK M, KOPINCOVA J, NOVA Z, URBANOVA A, MOKRA D, MOKRY J, CALKOVSKA A: The effect of pulmonary surfactant on the airway smooth muscle after lipopolysaccharide exposure and its mechanisms. Physiol Res 68 (Suppl 3): S275-S285, 2019. https://doi.org/10.33549/physiolres. 934410 